\title{
Industry 4.0 and construction supply chain management
}

\author{
Dennis Ayodeji Adeitan ${ }^{\mathrm{a}}$, Clinton Aigbavboa ${ }^{\mathrm{b}}$, Emmanuel Emem-Obong Agbenyeku $^{\mathrm{c}}$, Olufemi \\ Sylvester Bamisaye ${ }^{\mathrm{d}}$ \\ ${ }^{a}$ Postgraduate School of Operations Management, University of Johannesburg, Johannesburg 2028, South Africa \\ ${ }^{b}$ SARChl in Sustainable construction management and leadership in the built environment; Faculty of Engineering and the Built Environment, \\ University of Johannesburg, Johannesburg 2028, South Africa \\ ${ }^{c}$ Department of Chemical and Civil Engineering, University of Johannesburg, Johannesburg 2028, South Africa \\ ${ }^{d}$ Department of Mechanical Engineering, Federal University of Technology Akure, Akure 23434, Nigeria
}

\begin{abstract}
Industry 4.0 has contributed positively to establishing digital value-added supply chains to enable information flow between environment, clients, business partners and products. The aim of this article is to present a review on the features, elements and role of industry 4.0 to construction firms supply chain management. This article further reiterates the importance of digital industry 4.0 in construction firms supply chain management, especially on how construction industries and stake holders can reduce project delivery time, material and labor costs. The article reveals that industry 4.0 will have a high significant effect on the future of construction supply chain if it can identify crucial elements for improvement, such as speed, adjustability, measure of productivity, and high-test quality. The article also suggests further comprehensive research on how technological advancement can bring global competitiveness of the construction industry supply chain.
\end{abstract}

(C) 2019 The Authors. Published by Budapest University of Technology and Economics \& Diamond Congress Ltd.

Peer-review under responsibility of the scientific committee of the Creative Construction Conference 2019.

Keywords: Supply Chain Management; Construction; Industry 4.0; Global Competitiveness; Information Flow.

\section{Introduction}

The construction supply chain management is a technique applied in achieving integration between the several elements of the construction chain such as vendors, contractors, designers, clients, and direct suppliers (Papadopoulos et al., 2016). Construction supply Chain management helps to balance the information, cash, and material flows among set of construction companies to create value for their internal and external buyer (Xue et al, 2007). More specifically, the definitive characteristic of supply chain in construction means the total participating companies have dissimilar range, of both substantial and cognitive functioning, to the point of manufacturing. However, the planning of various materials to the position where different commodities meet is hindered by both substantial and cognitive distances (Dainty et al., 2001; O'Brien et al., 2008). This means identification of different characteristic that are novel to construction supply chain or construction projects will require some specific management effort such as strategy to build long time construction industry evolution and capabilities. Over the years, poor information flow between general contractors and subcontractors has contributed to current challenges 
Dennis Ayodeji Adeitan/ Proceedings of the Creative Construction Conference (2019) 053 https://doi.org/10.3311/CCC2019-053

been experienced in construction industry such as increase in lead times of equipment and materials delivery to the site, inefficiencies in demand, and lack of involvement problem solving. Owning to these challenges, construction firms and suppliers have emerged to take actions such as improving organizational participation among players in the construction chain and introduction of industry 4.0 routines, processes and operations to construction supply chain management. Although, construction industry experiences a distinct challenge than the manufacturing industry such as complicated interrelated processes occurring at locations and different stages of construction. Industry 4.0 has contributed positively to establishing digital value added supply chains to enable information flow between environment, clients, business partners and products through the automation of producing environment (kagermann et al., 2013; Dallasega, 2018). In today's global environment, information and data management is a meaningful intermediary in industry 4.0, it is done with the aid of cloud to collect, appraise and evaluate data efficiently, faster machine operations to manufacture quality goods at a less costs, boost productivity, and competitiveness in construction companies. Industry 4.0 impact to construction industry current forecast growth is reported by Construction Products Association (2016), which reveals that United Kingdom construction product sector is likely to reach its maximum output by 2019 and can grow over $£ 30$ billion by 2025 with cheaper \& timely deliveries of buildings because of the integration of automation, digitalization, industry 4.0, and building information modelling through supply chain management and direct United Kingdom construction economy. It is advisable that every firm must introduce swift digitalization, effective and agile internet of things, and large data evaluation to its processes because it decreases human factor in their activities (Li and Yang, 2017). It is a processes or technique which construction industry must be built upon in order to achieve intelligent systems, resource efficient direct economy and efficient products.

The aim of this article is to present a review on the features and role of industry 4.0 to construction firms supply chain management. Section two of the article identifies the interfaces of distinct functions that continue at the center of construction supply chain and four roles of supply chain in construction management. Section three discusses the headway in technology that comprises the establishment for Industry 4.0. Section four of the article discuss the policy framework of supply chain and the features of industry 4.0. Finally, a conclusion section.

\section{Supply chain management and construction industry}

The construction supply chain management is described as the collaboration of key determinant process in the construction supply chain and incorporation of major players involved in construction chain such as designers, clients, suppliers, and contractors (Xue et al., 2005). The key objective of construction supply chain is to improve construction performance, direct precise quantities of raw materials to the site, and improve client value while minimizing cost attributed to production, inventory and transportation. This means the Integration of digitalization and prefabrication method in transporting materials from construction site to the operation environment will improve quality, time and reduce cost. Although, the construction supply chain method is distinct from manufacturing operations in industries, supply chain management method can still be applicable in construction industry. The disruption in the construction operations is caused by failure in collaboration with its value supply chain which makes supply chain method a difficult task to attain among suppliers, designers, contractors, and clients (Christopher and Peck, 2004). The assembly and transportation of all type of materials to the site involves dissimilar supply chain framework with distinct time must be viewed. The designed supply chain framework includes; a) Engineer- to-Order b) Make-to-Order c) Make-to-Stock and d) Assemble-to-Order (Dallasega and Rauch, 2017; Dike and Kapogiannis et al., 2014).

Vrijhoef et al., (2001) and Akintoye et al., (2000) have identified some interfaces that are present within the conversion process and the construction supply chain. Table 1 highlighted the different interface and problem description that exists within the construction supply chain. 
Dennis Ayodeji Adeitan/ Proceedings of the Creative Construction Conference (2019) 053

https://doi.org/10.3311/CCC2019-053

Table 1. Summary of some general problems that exists within the construction supply chain

\begin{tabular}{|c|c|}
\hline Interfaces & Problem Description \\
\hline Feed and Engineering Interface & $\begin{array}{l}\text { Inaccurate certification, Design alteration, Wrong calculations, Prolong time for design revision and } \\
\text { approval }\end{array}$ \\
\hline Client Feed & Extended time for Design Changes and approval, No constructability \\
\hline $\begin{array}{l}\text { Engineering Procurement, } \\
\text { Vendors Interface }\end{array}$ & Incorrect data, Engineering designs not applicable for use \\
\hline Engineering Site Interface & Engineering personnel not present on site for the field engineering \\
\hline $\begin{array}{l}\text { Project Completion and } \\
\text { Commissioning }\end{array}$ & Complicated completion due to security concerns, Problems with residents. \\
\hline $\begin{array}{l}\text { Procurement and Logistics } \\
\text { Interface }\end{array}$ & $\begin{array}{l}\text { Lack of inaccurate logistic studies, ineffective logistics routes, permits \& licenses required, and customs } \\
\text { clearance setback. }\end{array}$ \\
\hline Logistics and construction Site & Big shipments, Lack of acceptable packing, bad weather or Political conditions, extended storage time \\
\hline Major Contractor Subcontractors & $\begin{array}{l}\text { Wrong and defective deliveries, Large shipments, Long storage period, Interfaces with several } \\
\text { subcontractors and suppliers, Poor training of contractor's suppliers }\end{array}$ \\
\hline $\begin{array}{l}\text { Suppliers and Subcontractors / } \\
\text { Site Interface }\end{array}$ & $\begin{array}{l}\text { Wrong and defective deliveries, Extended storage time, Contract planning, less productivity of many } \\
\text { subcontractors, Poor training of personnel }\end{array}$ \\
\hline $\begin{array}{l}\text { Commissioning and Operation } \\
\text { Interface }\end{array}$ & Unresolved quality and technical problems, Delayed operational time due to late completion \\
\hline
\end{tabular}

Source: Akintoye et al., (2000), authors' own editing.

Vrijhoef and Koskela (2001) reiterated the four roles of supply chain management which is concurrently applied by major contractors to maximize efficiency in construction management of construction site. The mentioned four vital roles of supply chain in construction are shown in figure 1 .

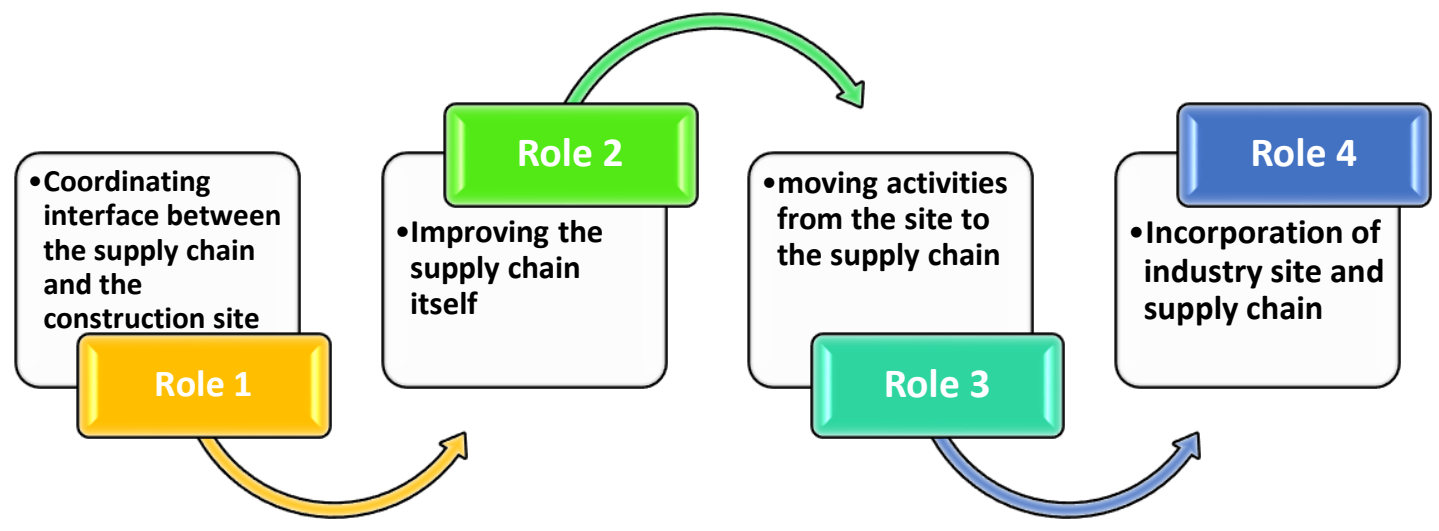

Figure 1: The four vital roles of supply chain management in construction, Source: Vrijhoef and Koskela (2001), authors' own editing.

From figure 1, the activities in role 1 implies that the contractor goal is on how to improve the material flow, labour flow, minimise duration of construction site activities, and reduce costs. This target may be achieved by coordinating the interrelation between the suppliers in the supply chain and construction site. Role 2 reveals that detailed material cost and analysis of time are crucial for distinguishing potentials in developing construction supply chains. Therefore, activities relating to storing of material or inventory and logistics cost may be directed to the supply chain itself with the aim of achieving quality in design at a reduce costs. The aim in Role 3 is on how direct suppliers or 
contractors can minimize the total costs and time of construction, it is done by transferring the activities from the construction site to the first point of value supply chain. Another way of minimizing the total costs and total time of construction is the Prefabrication technique which cancels almost all site activities from the manufacturing chain. Lastly, the goal in role 4 is finding new replacement for the incorporation of the site and the supply chain. The Clients, general and sub-contractors may focus on the incorporation of management, site manufacturing and enhancement of the construction supply chain since site manufacturing is entailed in supply chain management.

\section{Industry 4.0 concepts}

Industry 4.0 means the technique of increasing automation of the production space and value-added supply chain through interaction between clients, their location, and products. It can be referred to as an event that penetrates the entire value chain of an organisation through technological activities, increases clarity of procedures by making use of digitization, and finally incorporating value added chain into customer supply chain. It is a concept which started in the manufacturing sector but gradually transforming the construction industry through digitized means (kagermann et al., 2013; lasi et al., 2014). It is an elaborate strategy which was initiated by German government in association between industrial and manufacturing organisations with the aim of encouraging industrial modification and obtainment of a leadership role in today's global competitive producing sector (Bartodziej, 2017). In today's manufacturing environment, end consumers can choose from a variety of products, but they seem not to be satisfied with the value. Therefore, manufacturers are in a race to create personalized products while retaining value, customers, and surviving the worlds competitive market (Prahalad, 2004). industry 4.0 usefulness is the ability to link all scenarios involved in value added supply chain such as people, systems, relevant information in real time, and data of value-added flow across computers. The collection and analysis of information involves application of computerised technologies and strategy in linking the manufacturing and logistics value chain (Cappellin et al., 2017). It means the development of interconnected systems that allows large data collection within each other communication devices through the application of Internet of Things are the most characteristic of industrial revolution. According to Qin et al., (2016), the industry 4.0 agenda relies on the following factors; a) smart products capable of collecting and transmitting data to the central system with the aid of processors and sensors b) business activity that relies on the combination of information flow between manufacturers supply chain and trade-off real time data c) smart factory that form part of replacing real time data in a conditioned manner and the manufacturing activities are self-dependent d) consumers may order commodity with any function and redesign their order at any period of the manufacturing process.

According to rubmann et al., (2015), the enabling technologies that forms the foundation of industry 4.0 are characterized by remote, enhanced branches that combines together as a fully integrated, computerised, and enhanced manufacturing flow thereby leading to greater capability and connection between supply chain. Figure 2 shows nine foundational technology advancement of Industry 4.0

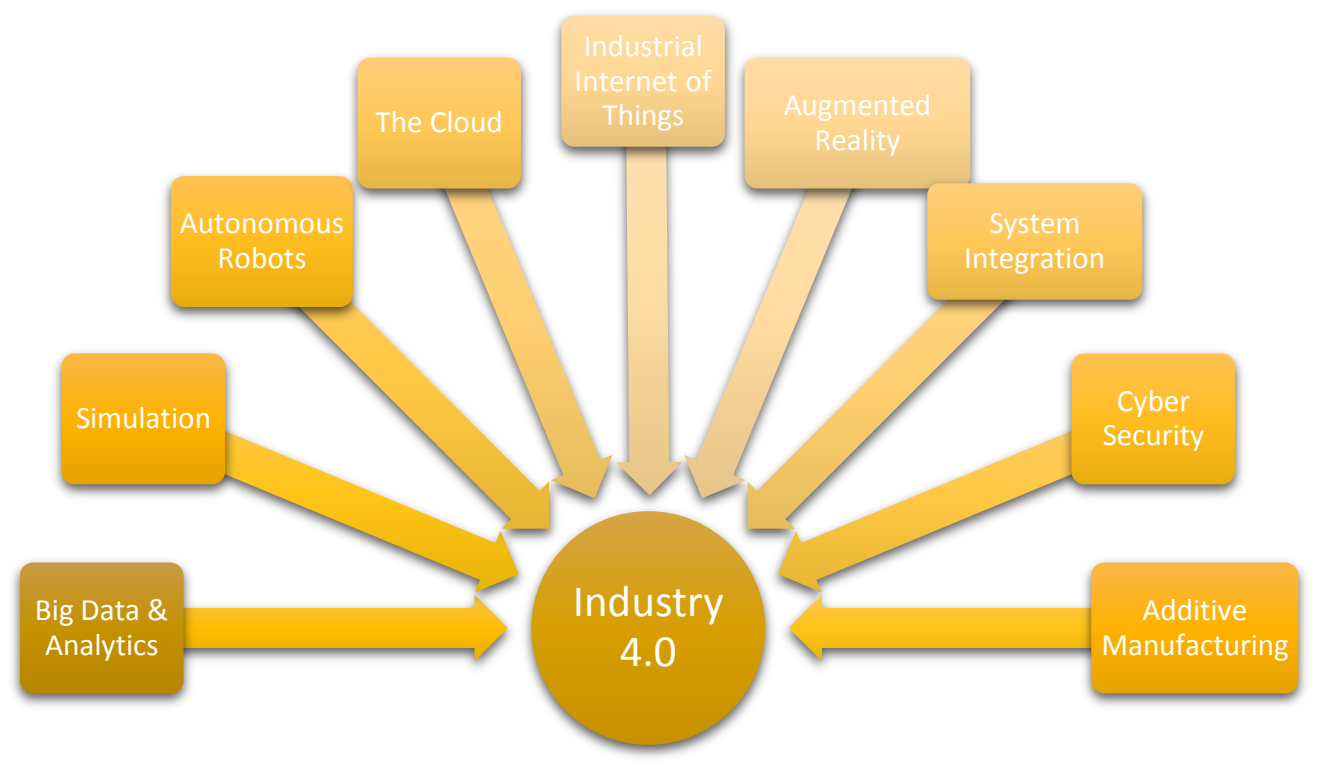


Dennis Ayodeji Adeitan/ Proceedings of the Creative Construction Conference (2019) 053

https://doi.org/10.3311/CCC2019-053

Figure 2: Nine foundational technology advances of industry 4.0, Source: Rubmann et al., (2015), authors' own editing.

Figure 2 shows that industry 4.0 can be transformed if only the sensors and ICT tools are connected along the valueadded chain beyond one industry. The connected sensors and IT systems are called cyberphysical systems because they interact and configure one another using approved internet-based protocols. Therefore, the functions of nine pillars of technological advances that form the core process for industry 4.0 in Figure 2 are; a) Augmented Reality: it comprises of devices that allows real time data to improve decision process and job procedures $b$ ) Additive Manufacturing: it allows firms in manufacturing specimens and completed products directly on the supply chain with a less transport distances through decentralized manufacturing systems c) Simulations: it allows the controller to perform test experiment and optimize the device functions for the next merchandise in line thereby reducing cost and machine set up time d) System Integration: it allocates personnels with real time data to correct defective work procedures throughout the entire supply chain e) Cybersecurity: protects the computer systems, industrial systems, and manufacturing lines ensuring a network security f) Big Data: it optimizes and analyse huge volume of data to enhance products quality and energy saving g) The cloud: large amounts of device data and connection will be made available by the cloud system and accessibility of production services at all times h) The Industrial Internet of Things: allows field devices and set of technologies to communicate, interact between artificial world and people, and with more centralized systems i) Autonomous robots: it performs different complex assignments which costs less than the robots used in today's manufacturing.

\section{Industry 4.0 and construction industry}

The construction industry experiences a high level of uncertainty and distinct constraint than the manufacturing industry to maximize productivity such as large volume of connected processes, and partaking players at different stages and in different site make the construction firms process challenging (arayici and coates, 2012). Construction sites are usually faced with obstacles in production processes, high variability, missing materials, handling of material, and unpredictability which makes linking of supply chains to the construction progress difficult. Therefore, industry 4.0 concepts, embedded systems, cloud computing, additive manufacturing, augmented reality, ProductLifecycle-Management, information technologies, and big data is vital in overcoming the individual challenges in construction supply chain deficiences ( $\mathrm{Li}$ and Yang, 2017). The building information management technology is important in the pre-construction phase because it combines with the location base service to track material. Another means of improving construction industry supply chain process is by simulating site management process in a virtual construction site to see if it can effectively monitor workers, tools, materials, and equipment. According to oesterreich and teuteberg (2016), the concepts of industry 4.0 is important in digital supply chains of the construction industry because it enables interaction and communication between clients, project managers, business partners, and construction sites. The policy framework of supply chain and its industrial competitiveness on the global market relies on the features of industry 4.0 (Nowotarski and Paslawski, 2017). Table 2 gives the functions and industry 4.0 key features. 
Dennis Ayodeji Adeitan/ Proceedings of the Creative Construction Conference (2019) 053

https://doi.org/10.3311/CCC2019-053

Table 2: Function and industry 4.0 key features

\begin{tabular}{ll}
\hline $\begin{array}{l}\text { Features of Industry } \\
4.0\end{array}$ & Functions \\
\hline $\begin{array}{l}\text { Interoperability } \\
\text { Virtualization }\end{array}$ & $\begin{array}{l}\text { Incorporation of people and smart factories to transmit with each other } \\
\text { A virtual copy of the smart factory is established by connecting sensor data with virtual plant specimen and }\end{array}$ \\
$\begin{array}{l}\text { secentralization } \\
\text { capability of cyber-physical components to make instruction of its own and manufacture it domestically } \\
\text { Modularity }\end{array}$ & the ability to collect and appraise real time data and evaluate the results. \\
& Adjustable properties of smart factories to replace or expand its individual modules.
\end{tabular}

Source: Nowotarski and Paslawski (2017), authors' own editing..

From Table 2, features of industry 4.0 such as decentralization, virtualization, real-time competency, modularity, and Interoperability can be useful to construction firms through the application of work flows in reducing material and labor costs, less in project delivery time and materials reduction through prefabrication of parts and additive manufacturing method. According to Ortiz (2009), the digitization of industry 4.0 in the construction chain is placed across departments and individual divisions which covers information gathering, evaluation of current data state of each value chain interaction, Integration of humans and smart production site to communicate with each other, and generate autonomous technologies.

The industrial revolution 4.0 will have a positive effect on future of construction supply chain since it comprises of three points growth (alaloul, 2018). The three points growth includes; a) Digitization of manufacturing: data blue print for organization and construction development, b) Automation: design for information sourcing from the construction site and other machines operation, and c) connecting construction sites to a supply chain: fully conditioned data exchange.

Manufacturing firms will adopt Industry 4.0 at different stage and in distinct ways such that organizations with a top level of article variants will take advantage from a greater degree of changeable process that can create productivity gains and reduce error rate (Rüßmann, et al., 2015). The set priorities among production processes and industry 4.0 are as follows:

- Finding crucial areas for amendment such as speed, adjustability, measure of productivity, and high-test quality. Followed by, examining how nine foundational technology advancement of industry will bring improvement in the assigned areas.

- Study the lengthy impact on the staff and plan vital staff planning. Then readjust roles, recruiting, and technical training to equip the staff with comprehensive IT skills.

- Manufacturers and suppliers must try to customize infrastructure and knowledge as they involve the Industry 4.0 technologies

- System suppliers must assemble a scenario-based vision of the long-term industry goals and ensure that their design will equip them for the most likely scenarios.

- Suppliers need to understand how they can introduce Industry 4.0 technologies in order to offer the best benefits to their customers. 
Dennis Ayodeji Adeitan/ Proceedings of the Creative Construction Conference (2019) 053

https://doi.org/10.3311/CCC2019-053

\section{CONCLUSION}

Industry 4.0 is a means of increasing computerization of the construction industry and digital value-added supply chain to enable interaction between clients, their environment and products. Over the years, lack of information flow between general contractors and subcontractors has contributed to current challenges been experienced in construction industry such as increase in lead times of equipment and materials delivery to the site. Therefore, this study proposes the adoption of technologies to secure constant information flows to the construction site to avoid disturbance to the workflow. It also important for contractors to focus on forming relationship among players in the construction chain, processes, operations, and direct suppliers. Lastly, in order for future development of industry 4.0 in construction supply chain management, producers, suppliers, organizations, businesses and government must work together to integrate framework and education as they adopt industry 4.0 tools.

\section{References}

1. Xue X, Wang Y, Shen Q, Yu X. Coordination mechanisms for construction supply chain management in the internet environment. International Journal of Production Management. 2007; 25:150-157. https://doi.org/10.1016/j.ijproman.2006.09.006

2. O’Brien WJ, Formoso CT, Vrijhoef R, London KA. Construction supply chain management handbook, CRC Press, Boca Raton, FL, 2008.

3. Dainty AR, Millett SJ, Briscoe GH. New perspectives on construction supply chain integration. International Journal of Supply Chain Management. 2001;6: 63-173. https://doi.org/10.1108/13598540110402700

4. Vrijhoef R Koskela L. The four roles of supply chain management in construction. European Journal of Purchasing Supply Management. 2000; 6:169-178. 1https://doi.org/0.1016/S0969-7012(00)00013-7

5. Dike U, Kapogiannis G. A conceptual model for improving construction supply chain performance. Proceedings of the 30th Annual Association of Researchers in Construction Management Conference. 2014; 1-11.

6. Kagermann H, Helbig J, Hellinger A, Wahlster W. Recommendations for Implementing the Strategic Initiative INDUSTRIE 4.0: Securing the Future of German Manufacturing Industry, acatech, Munich, 2013.

7. Lasi H, Fettke P, Kemper HG, Feld T, Hoffmann M. Industry 4.0. Business Information Syststem Engineering.2014; 239-242.

8. Oesterreich TD, Teuteberg F. Understanding the implications of digitisation and automation in the context of Industry 4.0: A triangulation approach and elements of a research agenda for the construction industry, Computer Indusry.2016; 83:121-139. https://doi.org/10.1016/ j.compind.2016.09.006

9. Li J, Yang H. A research on development of construction industrialization based on BIM technology under the background of Industry 4.0, MATEC Web of Conferences. 2017: 2046. https://doi.org/10.1051/matecconf/201710002046

10. Arayici Y, Coates P. A system engineering perspective to knowledge transfer: a case study approach of BIM adoption. Virtual Reality Human Computer Interaction, InTech. 2012; 179-206.

11. Bartodziej CJ. The Concept Industry 4.0: An Empirical Analysis of Technologies and Applications in Production Logistics, Springer Gabler, Wiesbaden, Germany. 2017

12. Cappellin R, Baravelli M, Bellandi M, Camagni M, Capasso R, Ciciotti S, Marelli E. Investimenti, innovazione e nuove strategie d'impresa. Quale ruolo per la nuova politica industriale e regionale?, Egea editore, Milano. 2017.

13. Prahalad CK, Ramaswamy V. Co-creation experiences: the next practice in value creation. Journal of Interactive Marketing. 2004; 5-14.

14. Qin J, Liu J, Grosvenor, R. (2016). A categorical framework of manufacturing for industry 4.0 and beyond, Procedia CIRP. 2016 ; 173-178. https://doi.org/10.1016/j.procir.2016.08.005

15. Dallasega $P$ and Rauch E. Sustainable construction supply chains through synchronized production planning and control in engineer-to-order enterprises. Sustainability. 2017; 9(10): 1-25.

16. Dallasega P. Industry 4.0 fostering construction supply chain management: lessons learned from engineer-to-order Suppliers. IEEE Engineering Management Review. 2018; 46(3). https://doi.org/10.1109/EMR.2018.2861389

17. Xue X, Li X, Shen Q, Wang Y. (2005) ‘An agent-based framework for supply chain coordination in construction’ Automation in Construction. 2005; 14: 413-430. https://doi.org/10.1016/j.autcon.2004.08.010

18. Christopher M, and Peck H. Building the resilient supply chain. The International Journal of Logistics Management. 2004; $15(2): 1-14$. https://doi.org/10.1108/09574090410700275

19. Ortiz O, Castells F, Sonnemann G. Sustainability in the construction industry: A review of recent developments based on LCA. Construction and Building Materials. 2009; 23(1): 28-39. https://doi.org/10.1016/j.conbuildmat.2007.11.012

20. Alalou WS, Liew MS, Zawawi NA, Mohammed BS. Industry Revolution IR 4.0: Future Opportunities and Challenges in Construction Industry. MATEC Web of Conferences. 2018. 203, 02010. https://doi.org/10.1051/matecconf/201820302010

21. Akintoye A, Macintosh G, Fitzgerald E. A survey of supply chain collaboration and management in the UK construction industry, European Journal of Purchasing and Supply Management. 2000. http://dx.doi.org/10.1016/S0969-7012(00)00012-5

22. Vrijhoef R, Koskela L, Howell G. Understanding construction supply chains: an alternative interpretation.” Proceedings 9th Annual Conference International Group for Lean Construction, Singapore. 2001.

23. Papadopoulos GA, Zamer N, Gayialis SP, Tatsiopoulos IP. Supply Chain Improvement in Construction Industry. Universal Journal of Management. 2016. 4(10): 528-534. https://doi.org/10.13189/ujm.2016.041002

24. Construction Products Association. Digitalisation, Industry 4.0 and the Circular Economy October 2016. ISBN: 978-1-909415-21-8, www.constructionproducts.org.uk 
Dennis Ayodeji Adeitan/ Proceedings of the Creative Construction Conference (2019) 053

https://doi.org/10.3311/CCC2019-053

25. Rüßmann, M, Lorenz M, Gerbert P, Waldner M, Justus J, Engel P, Harnisch M. Industry 4.0: the future of productivity and growth in manufacturing industries. The Boston Consulting Group. www.bcg.com.

26. Nowotarski P, Paslawski J. Industry 4.0 Concept Introduction into Construction SMEs. IOP Conference Series: Materials Science and Engineering. 2017; 245:052043 